\title{
Correction to: Prediction of risk factors and outcomes of neonatal acute kidney injury
}

\author{
Kumail AlGadeeb $^{1} \cdot$ Mostafa Qaraqei $^{2} \cdot$ Rahma Algadeeb $^{3} \cdot$ Hassan Faqeehi $^{4} \cdot$ Abdulrahman Al-Matary $^{1} \mathbb{C}$
}

Published online: 15 September 2021

(c) The Author(s) 2021

\section{Correction to: Journal of Nephrology https://doi.org/10.1007/s40620-021-01130-x}

The co-authors and their affiliations are omitted in the published article.

The correct list of author names and their affiliations are copied below:

Kumail AlGadeeb ${ }^{1}$, Mostafa Qaraqei ${ }^{2}$, Rahma Algadeeb ${ }^{\mathbf{3}}$, Hassan Faqeehi ${ }^{4}$, Abdulrahman Al-Matary ${ }^{1, *}$

1. Neonatology department, Maternity and children hospital, Alhasa, Saudi Arabia

2. Neonatology department, King Fahad Medical city, Riyadh, Saudi Arabia

3. Postgraduate center for preventive medicine, Alhasa, Saudi Arabia

4. Department of Nephrology, Children's hospital, King Fahad Medical City, Riyadh, Saudi Arabia

*Corresponding author, amatary@yahoo.com

The original article has been corrected.

Open Access This article is licensed under a Creative Commons Attribution 4.0 International License, which permits use, sharing, adaptation, distribution and reproduction in any medium or format, as long as you give appropriate credit to the original author(s) and the source, provide a link to the Creative Commons licence, and indicate if changes were made. The images or other third party material in this article are included in the article's Creative Commons licence, unless indicated otherwise in a credit line to the material. If material is not included in the article's Creative Commons licence and your intended use is not permitted by statutory regulation or exceeds the permitted use, you will need to obtain permission directly from the copyright holder. To view a copy of this licence, visit http://creativecommons.org/licenses/by/4.0/.

Publisher's Note Springer Nature remains neutral with regard to jurisdictional claims in published maps and institutional affiliations.

The original article can be found online at https://doi.org/10.1007/ s40620-021-01130-x.

Abdulrahman Al-Matary

amatary@yahoo.com

1 Neonatology Department, Maternity and Children Hospital, Alhasa, Saudi Arabia

2 Neonatology Department, King Fahad Medical City, Riyadh, Saudi Arabia

3 Postgraduate Center for Preventive Medicine, Alhasa, Saudi Arabia

4 Department of Nephrology, Children's hospital, King Fahad Medical City, Riyadh, Saudi Arabia 